\title{
Enterococcus gallinarum carrying the vanA gene cluster: first report in Brazil
}

I.L.B.C. Camargo ${ }^{1}$, A.L. Barth², K. Pilger ${ }^{2}$,

B.G.S. Seligman ${ }^{2}$, A.R.L. Machado ${ }^{2}$ and A.L.C. Darini ${ }^{1}$

\author{
1Departamento de Análises Clínicas, Toxicológicas e Bromatológicas, \\ Faculdade de Ciências Farmacêuticas de Ribeirão Preto, \\ Universidade de São Paulo, Ribeirão Preto, SP, Brasil \\ ${ }^{2}$ Unidade de Pesquisa Biomédica, Serviço de Patologia Clínica, \\ Hospital de Clínicas de Porto Alegre, Porto Alegre, RS, Brasil
}

\author{
Correspondence \\ A.L.C. Darini \\ Departamento de Análises Clínicas \\ Toxicológicas e Bromatológicas \\ Faculdade de Ciências Farmacêuticas \\ de Ribeirão Preto, USP \\ Av. do Café, s/n \\ 14040-903 Ribeirão Preto, SP \\ Brasil \\ E-mail: aldarini@fcfrp.usp.br
}

A preliminary version of this study was presented at the

I South Brazilian Congress of Clinical Microbiology, Curitiba, PR, Brazil, August 9-11, 2002.

Research supported by FAPESP (No. 99/12233-0) and FIPE/HCPA (No. 01/203). I.L.B.C. Camargo was the recipient of a CNPq fellowship (No. 130486/2001-9).

Received March 10, 2004

Accepted July 15, 2004

\begin{abstract}
In 2000, Enterococcus faecalis resistant to vancomycin was first reported at a tertiary hospital in Porto Alegre, southern Brazil. The resistance spread to other hospitals and surveillance programs were established by hospital infection committees to prevent the spread of vancomycin-resistant enterococci. In February 2002, an isolate initially identified at the genus level as Enterococcus was obtained by surveillance culture (rectal swab) from a patient admitted to a hospital for treatment of septic arthritis in the shoulder. The isolate proved to be resistant to vancomycin by the disc diffusion method and confirmed by an E-test resulting in a minimal inhibitory concentration of $\geq 256$ $\mu \mathrm{g} / \mathrm{ml}$. This isolate was sent to a reference laboratory (Laboratório Especial de Bacteriologia e Epidemiologia Molecular, Faculdade de Ciências Farmacêuticas de Ribeirão Preto, USP) for further study and proved to be an E. gallinarum by the polymerase chain reaction (PCR) using specific primers for the species. Due to the phenotype of unusually high vancomycin resistance, the isolate presumably had the resistance genes (vanA and vanB) and this was confirmed by PCR, which indicated the presence of the vanA gene. A 10.8-kb Tn1546related transposon was also identified by long-PCR. Interspecies transfer of the vancomycin-resistance gene from the donor E. gallinarum was performed in a successful conjugation experiment in vitro, using E. faecium GE-1 and E. faecalis $\mathrm{JH} 22$ as receptors. This is the first report of the detection of a vanA determinant naturally acquired by $E$. gallinarum in Brazil, indicating the importance of characterizing VRE by both phenotype and genotype methods.
\end{abstract}

Enterococci have emerged as increasingly quired pathogens. First described in 1988 in France and England $(1,2)$, glycopeptide-resistant enterococci have been isolated in Brazil since 1996, when the first case of vancomycin-resistant enterococci (VRE) due to a Enterococcus faecium $\mathrm{VanD}_{4}$ was reported in Curitiba (Paraná State) $(3,4)$. Further VRE important nosocomial and community-ac-
Key words

- Enterococcus gallinarum

- VanA phenotype

- Vancomycin

- Resistance isolates (E. faecium with the $\operatorname{van} \mathrm{A}$ gene) were reported in São Paulo State $(5,6)$.

Glycopeptide resistance in enterococci is associated with a variety of phenotypes and genotypes. VanA and VanB are the two major genetically distinct forms of acquired resistance. The VanA phenotype displays a high level of resistance to vancomycin and teicoplanin but the VanB phenotype displays 
a high level of resistance only to vancomycin. However, both have been found primarily in E. faecalis and E. faecium (7). In contrast, E. gallinarum, E. casseliflavus and E. flavescens have an intrinsic low-level resistance to vancomycin due to the $\mathrm{VanC}$ phenotype (7). The vanC-1 gene is specific for E. gallinarum, and vanC-2/3 is specific for $E$. casseliflavus and E. flavescens. Nevertheless, a few cases of vanA and vanB genes acquired by $E$. gallinarum have been reported: in Switzerland (8), Australia (9), Italy (10), Belgium (11), and Taiwan (12).

In 2000, vancomycin-resistant $E$. faecalis was first described at a tertiary hospital in Porto Alegre, southern Brazil. The resistance spread to other hospitals and surveillance programs were established by the hospital infection committees in order to prevent the spreading of VRE. In February 2002, an isolate initially identified at the genus level as Enterococcus by a few basic tests (Gram, bile esculin, catalase, growth on $6.5 \%$ $\mathrm{NaCl}$ and L-pyrrolidonyl-ß-naphthylamide, PYR) was obtained at Hospital de Clínicas de Porto Alegre by surveillance culture (rectal swab) from a patient admitted to the hospital due to septic arthritis in the shoulder. The isolate proved to be resistant to vancomycin by the disc diffusion method

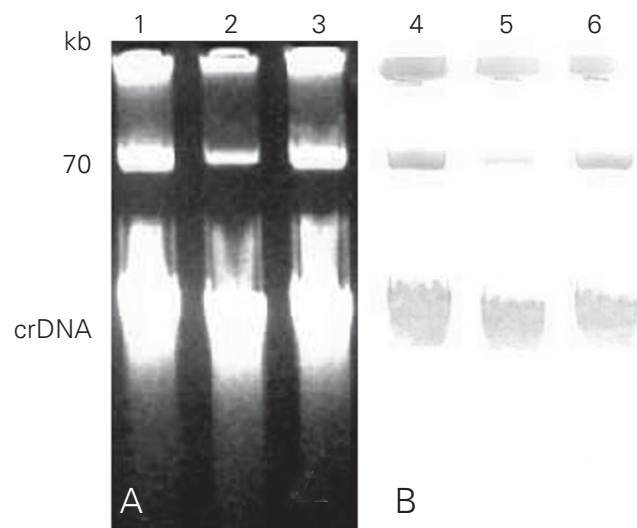

Figure 1. Conjugation experiments. A, Plasmid extraction product in $1 \%$ agarose gel; $B$, Southern blotting hybridization of vanA probes in a nylon membrane. Lane 1, E. gallinarum ET193; lane 2, transconjugant of E. faecium GE-1; lane 3, transconjugant of $E$. faecalis $\mathrm{JH} 22$. $\mathrm{crDNA}=$ chromosomal DNA carried out according to NCCLS (13) and this was confirmed by the E-test (AB Biodisk, Sweden) resulting in a minimal inhibitory concentration of $\geq 256 \mu \mathrm{g} / \mathrm{ml}$.

This isolate was sent to a reference laboratory (Laboratório Especial de Bacteriologia e Epidemiologia Molecular, Faculdade de Ciências Farmacêuticas de Ribeirão Preto) for further study and proved to be an $E$. gallinarum (termed ET193) by the polymerase chain reaction (PCR) using specific primers for the species (11). Due to the phenotype of unusually high level of vancomycin resistance, the isolate was tested for the presence of specific resistance genes (vanA and $v a n B$ ) by PCR, which indicated the presence of the vanA gene $(14,15)$.

The high level of vancomycin resistance among enterococcus isolates is often mediated by a self-transferable plasmid that has acquired the Tn1546-related transposons, which carry the vanA gene cluster (16). We demonstrated a $\operatorname{Tn} 1546$-related 10.8-kb transposon which was found to be identical to the Tn1546 prototype in the E. gallinarum ET193 isolate by long-PCR (17).

Interspecies transfer of the vancomycin resistance determinant from the $E$. gallinarum ET193 donor was successfully carried out by a conjugation experiment in vitro using $E$. faecium $\mathrm{GE}-1$ and E. faecalis $\mathrm{JH} 22$ as receptors (18). After successful conjugation, several transconjugants were obtained by selection on plates containing $4 \mu \mathrm{g} / \mathrm{ml}$ vancomycin, $200 \mu \mathrm{g} / \mathrm{ml}$ rifampicin, and $100 \mu \mathrm{g} / \mathrm{ml}$ fusidic acid. Plasmid extraction was performed and a plasmid of about $70 \mathrm{~kb}$ was found in the transconjugants and in the $E$. gallinarum ET193 donor isolate. Eventually, the electrophoretic profile was analyzed by Southern blot and hybridization using a digoxigenin-labeled vanA gene probe in order to locate the presence of the gene. The gene-specific probe was bound to both plasmids and chromosomal DNA of the several transconjugants and donor E. gallinarum ET193 (Figure 1). 
This is the first case of E. gallinarum carrying the vanA gene cluster isolated in Brazil. As the patient was also colonized by a vanA genotype vancomycin-resistant $E$. faecalis, it is reasonable to speculate that this gene cluster was transferred from $E$. faecalis to E. gallinarum in vivo. This was, most probably, a natural acquisition of a peculiar high level resistance gene by the E. galli- narum species and indicates the importance of characterizing VRE by both phenotype and genotype methods.

\section{Acknowledgments}

The authors thank Izabel Cristina Vanzato Palazzo for technical assistance during the transfer experiments.

\section{References}

1. Uttley AHC, Collins CH, Naidoo J \& George RC (1988). Vancomycinresistant enterococci. Lancet, 1: 57-58.

2. Leclercq R, Derlot E, Duval J \& Courvalin P (1988). Plasmid-mediated resistance to vancomycin and teicoplanin in Enterococcus faecium. New England Journal of Medicine, 319: 157-161.

3. Dalla Costa LM, Souza DC, Martins LTF, Zanella RC, Brandileone MC, Bokermann S, Sader HS \& Souza APHM (1998). Vancomycinresistant Enterococcus faecium: First case in Brazil. Brazilian Journal of Infectious Diseases, 3: 160-163.

4. Dalla Costa LM, Reynolds PE, Souza HA, Souza DC, Palepou MF \& Woodford N (2000). Characterization of a divergent VanD-type resistance element from the first glycopeptide-resistant strain of Enterococcus faecium isolated in Brazil. Antimicrobial Agents and Chemotherapy, 44: 3444-3446.

5. Cereda RF, Gales AC, Silbert S, Jones RN \& Sader HS (2002). Molecular typing and antimicrobial susceptibility of vancomycinresistant Enterococcus faecium in Brazil. Infection Control and Hospital Epidemiology, 23: 19-22.

6. Zanella RC, Valdetaro F, Lovgren M, Tyrrel GJ, Bokermann S, Almeida SCG, Vieira VSD \& Brandileone MCC (1999). First confirmed case of a vancomycin-resistant Enterococcus faecium with Van A phenotype from Brasil: isolation from a meningitis case in São Paulo. Microbial Drug Resistance, 5: 159-162.

7. Woodford N (1998). Glycopeptide-resistant enterococci: a decade of experience. Journal of Medical Microbiology, 47: 849-862.

8. Liassine N, Frei R, Jan I \& Auckenthaler R (1998). Characterization of glycopeptide-resistant Enterococci from a Swiss Hospital. Journal of Clinical Microbiology, 36: 1853-1858.

9. Schooneveldt JM, Marriott RK \& Nimmo GR (2000). Detection of vanB determinant in Enterococcus gallinarum in Australia. Journal of Clinical Microbiology, 38: 3902.

10. Biavasco F, Paladini C, Vignaroli C, Foglia G, Manso E \& Varaldo PE (2001). Recovery from a single blood culture of two Enterococcus gallinarum isolates carrying both vanC-1 and vanA cluster genes and differing in glycopeptide susceptibility. European Journal of
Clinical Microbiology and Infectious Diseases, 20: 309-314.

11. Dutka-Malen S, Blaimont B, Wauters G \& Courvalin P (1994). Emergence of high-level resistance to glycopeptides in Enterococcus gallinarum and Enterococcus casseliflavus. Antimicrobial Agents and Chemotherapy, 7: 1675-1677.

12. Lu JJ, Wu JC, Chiueh TS, Perng CL, Chi WM \& Lee WH (2000). Characterization of a highly glycopeptide-resistant Enterococcus gallinarum isolate. Journal of the Formosan Medical Association, 4: 305-310.

13. NCCLS (2002). Performance Standards for Antimicrobial Susceptibility Testing. Twelfth Informational Supplement M100-S12. National Committee for Clinical Laboratory Standards, Villanova, PA, USA.

14. Woodford N, Morrison D, Johnson AP, Briant V, George RC \& Cookson B (1993). Application of DNA probes for rRNA and vanA genes to investigation of a nosocomial cluster of vancomycin-resistant Enterococci. Journal of Clinical Microbiology, 31: 653-658.

15. Woodford N, Morrison D, Johnson AP, Bateman AC, Hasting JGM \& Cookson B (1995). Plasmid-mediated vanB glycopeptide resistance in enterococci. Microbial Drug Resistance, 1: 235-240.

16. Molinas AM, Depardieu F \& Courvalin P (1993). Characterization of Tn1546, a Tn3-related transposon conferring glycopeptide resistance by synthesis of depsipeptide peptidoglycan precursors in Enterococcus faecium BM4147. Journal of Bacteriology, 175: 117127.

17. Woodford N, Watson AP \& Chadwick PR (1997). Investigation by long PCR of genetic elements mediating VanA glycopeptide resistance in enterococci from uncooked meat in South Manchester. In: Horaud T, Bouvet A, Leclerq R, de Montelos H \& Sicard M (Editors), Streptococci and the Host 1997. Plenum Press, New York, 406-412.

18. Tremlett $\mathrm{CH}$, Brown DFJ \& Woodford N (1999). Variation in structure and location of VanA glycopeptide resistance elements among enterococci from a single patient. Journal of Clinical Microbiology, 17: 818-820. 